\title{
TEORI PENGETAHUAN IMMANUEL KANT DAN IMPLIKASINYA TERHADAP BATAS ILMU
}

\author{
Irfan Noor \\ Dosen Fakultas Ushuluddin IAIN Antasari \\ Jl. Sei. Andai Komp. PWI Blok F No. 40 RT. 40 Banjarmasin \\ Email: irfan_al.alabij@yahoo.com. HP: 081331336942 \\ Diterima 10 Nopember 2009/Disetujui 15 Desember 2009

\begin{abstract}
In modern philosophy, the discourse on the border of knowledge has developed, especially when positivism has become a dominant paradigm. In fact the roots of its epistemological problems can be found in Immanuel Kant's theory of knowledge. Kant's view of the conditions of possibility of buman mind eventually leads to a dogma that what can be investigated is only the phenomena. This dogma has become the basis for positivism to establish the knowledge border.
\end{abstract}

Kata kunci: teori pengetahuan kritis, inderawi, rasio, intelek, batas ilmu

\section{Pendahuluan}

Perdebatan tentang batas cakrawala ilmu pengetahuan dalam filsafat ilmu telah menjadi perdebatan yang krusial di masa-masa awal perkembangan ilmu-ilmu sosial-humaniora. Apabila ditelisik lebih jauh maka, pada dasarnya, tidak bisa dilepaskan dari wacana epistemologi yang dibangun oleh Immanuel Kant pada kisaran abad ke-17 dan ke18. Dalam abad-abad ini, ilmu pengetahuan tampil sebagai suatu disiplin ilmu yang universal dengan premis yang pasti dan metodenya yang hanya dapat diperdebatkan dengan mengambil sikap skeptisisme filosofis. ${ }^{1}$

${ }^{1}$ Toeti Heraty Noerhadi, "Dialog Filsafat dengan Ilmu-Ilmu Pengetahuan", [Pidato Pengukuhan Guru Besar], (Jakarta: Universitas Indonesia, 1994), h. 1-16. 
Sejak paradigma fisika Newtonian dianggap sebagai satu-satunya dasar yang sahih untuk melandasi perkembangan ilmu pengetahuan, maka paradigma fisika itu cenderung mendominasi paradigma ilmu pengetahuan abad 17 dan 18 karena tingkat kepastian dan ketepatan hasil-hasil penyelidikannya yang eksperimental dan matematis. Dampak dari dominasi tersebut adalah krisis identitas, khususnya pada filsafat. Filsafat yang bersifat reflektif tidak memiliki kepastian ala fisika, maka cenderung dianggap tidak ilmiah.

Dalam konteks inilah, Kant tampil ke atas panggung filsafat modern untuk melakukan pembaharuan. Salah satu pembaharuan Kant yang sangat berpengaruh terhadap perkembangan filsafat modern adalah pembaharuan di bidang epistemologi yang memiliki implikasi atas berkembangnya perdebatan batas cakrawala ilmu pengetahuan dalam filsafat ilmu guna memberikan legitimasi perkembangan ilmuilmu sosial-humaniora.

\section{Kehidupan dan Karir Intelektual Immanuel Kant (1724-1804)}

Immanuel Kant adalah seorang filsuf besar yang pernah tampil dalam pentas pemikiran filosofis zaman Aufklarung Jerman menjelang akhir abad ke-18. Kant lahir di Konigsberg, sebuah kota kecil di Prussia Timur, pada tanggal 22 April 1724. ${ }^{2}$ Kant lahir sebagai anak keempat dari suatu keluarga miskin. Orang tua Kant adalah seorang pembuat pelana kuda dan penganut setia gerakan Pietisme. Pada usia delapan tahun Kant memulai pendidikan formalnya di Collegium Fridericianum, sekolah yang berlandaskan semangat Pietisme. Di sekolah ini, Kant dididik dengan disiplin sekolah yang keras. Sebagai seorang anak, Kant diajarkan untuk menghormati pekerjaan dan kewajibannya, suatu sikap yang kelak amat dijunjung tinggi sepanjang hidupnya. Di sekolah ini pula, Kant mendalami bahasa Latin, bahasa yang sering dipakai oleh kalangan terpelajar dan para ilmuwan saat itu untuk mengungkapkan pemikirannya.

${ }^{2}$ Frederick Copleston, A History of Philosophy, Vol. 6, (From Wolff to Kant), (London: Burns and Oates Ltd., 1960), h. 180. 
Di awal kehidupannya, Kant tidak banyak memiliki keistimewaan yang menonjol di tengah-tengah masyarakat Prusia Timur. Karakter pribadinya cenderung menyukai kehidupan yang tenang, sehingga Kant tidak pernah aktif dalam politik sebagaimana Machiavelli atau Hegel. Begitu juga Kant tidak pernah memiliki pengalaman yang penuh gejolak dan tantangan, seperti yang pernah dialami Sokrates, Bruno, Spinoza, atau Rousseau. Kant juga tidak banyak mengadakan perjalanan yang jauh, sebagaimana Descartes atau Leibniz. Oleh karena itu, tidak mengherankan apabila seluruh hidup Kant lebih banyak dihabiskan di Prussia Timur dan lebih menyukai duduk-duduk, membaca bukubuku serta melakukan hal-hal yang berkaitan dengan refleksi. ${ }^{3}$

Kant mulai menjalani pendidikan formalnya di Kolose Fredericianum antara tahun 1732-1740. Setelah lulus dari Kolose ini, Kant melanjutkan pendidikannya ke universitas di kota kelahirannya ini juga. Di universitas ini, Kant sangat mengagumi Professor Martin Knutzen, dosen yang kelak sangat mempengaruhinya, yang mengajar logika dan metafisika, sehingga Kant mendapat pengaruh rasionalisme Leibniz dan Wolff serta mendapat wawasan yang luas tentang fisika Newton dan sistem metafisika yang berkembang masa itu. ${ }^{4}$

Di akhir karir intelektualnya, Kant menamakan filsafatnya sebagai "kritisisme", sebab ia memperbaharui filsafat-filsafat sebelumnya yang bersifat dogmatis. Oleh karena itu, perjalanan intelektual Kant sebagai filsuf dapat dibagi ke dalam dua periode. Pertama adalah periode pra-kritis, suatu masa dimana ia masih menganut dogmatisme Leibniz dan Wolff. Kedua adalah periode kritis, suatu masa dimana ia membangun sintesis yang menghasilkan sebuah cara berfilsafat baru yang menjadi pijakan dalam sejarah filsafat modern. Namun demikian, secara pasti sulit diketahui saat mana Kant mengakhiri periode pertama dan mulai menjalani periode kedua. Secara umum diduga peralihan tersebut terjadi sejak Kant dikukuhkan sebagai Professor di tahun 1770,

${ }^{3}$ Franki Budi Hardiman, Filsafat Modern: Dari Machiavelli sampai Nietzsche, (Jakarta: Gramedia, 2004), h. 129.

${ }^{4}$ Justus Hartnack, Kant's Theory of Knowledge, (New York: Brace and World Inc, 1967), h. 3-9. 
dimana ia pernah mengatakan bahwa Hume telah membangunkannya dari "tidur dogmatis"-nya. Di masa tersebut, tepatnya pada tahun 1781, Kant menerbitkan bukunya yang pertama Kritik der Reinen Vernunft (Kritik atas Rasio Murni), dan selanjutnya pada tahun 1788 menerbitkan buku Kritik der Praktischen Vernunft (Kritik atas Rasio Praktis), serta tahun 1790 menerbitkan buku Kritik der Urteilskraft (Kritik atas Daya Pertimbangan). ${ }^{5}$

Pada tanggal 12 Februari 1804, Kant meninggal dunia dalam usia delapan puluh tahun dan dimakamkan di Konigsberg (sekarang bernama Kaliningrad), Prusia Timur.

\section{Sintesis Kant terhadap Rasionalisme dan Empirisme}

Dalam kerangka sejarah filsafat Barat, Immanuel Kant hidup dalam masa dimana ilmu-ilmu alam yang dirintis Newton mencapai puncak pamor tertingginya, namun kemajuan ilmu yang sangat pesat itu tidak dapat diimbangi oleh filsafat. Hal tersebut, bagi Kant, merupakan teka-teki yang harus dijawab. Bagaimana hal itu mungkin? Apakah ilmu pengetahuan khususnya ilmu alam tersebut memiliki cukup dasar yang kokoh untuk dianuti ? Sementara itu di ranah dunia filsafat berkembang dua aliran pemikiran yang secara terus-menerus berkutat dalam perbedaan, yaitu rasionalisme ala Leibniz-Wolff dan empirisme, terutama yang dikembangkan oleh David Hume. Masalah pokok yang dipertentangan oleh kedua aliran filsafat ini adalah "objektivitas pengetahuan”. Apakah pengetahuan yang sungguh-sungguh objektif itu berasal dari rasio atau berasal dari pengalaman?

Bentrokan ini memaksa Kant memikirkan unsur-unsur mana di dalam pemikiran manusia yang berasal dari pengalaman dan unsurunsur mana yang telah terdapat dalam rasio manusia. Di satu pihak, Leibniz berpendapat bahwa sumber pengetahuan manusia adalah rasionya saja, dan bukan pengalaman. Dari sumber pengetahuan inilah bisa "diturunkan" kebenaran yang umum dan mutlak perlu. Sedangkan di pihak lain, Hume mengajarkan bahwa pengalamanlah sumber pengetahuan itu. Pengetahuan rasional mengenai sesuatu terjadi setelah

${ }^{5}$ Copleston, A History of Philosophy ....., h. 180-185. 
sesuatu itu dialami terlebih dahulu. Bagi Kant, kedua pendapat di atas berat sebelah. Kendati Kant mengagumi pemikiran Hume, filsuf yang telah membangunkan Kant dari "tidur dogmatik"-nya, namun ia tidak bisa menerima skiptisisme Hume, yaitu pandangan Hume bahwa "dalam ilmu pengetahuan tidak bisa diperoleh kepastian".

Posisi Kant, dalam pertentangan ini, bukan semata-mata mengambil-alih dan memadukan dua aliran pemikiran itu kepada satu sistem. Bagi Kant, mengikuti salah satu aliran pemikiran di atas bukanlah menyelesaikan masalah. Kedua-duanya dianggap keliru; kekeliruan rasionalisme adalah pengabaiannya atas posisi penting pengalaman dan lebih mementingkan rasio, pengertian dan aspek-aspek statis. Sedangkan empirisisme lebih mementingkan pengalaman dan aspek-aspek dinamis, tetapi tidak memiliki konsep untuk menggambarkan pengalaman.

Dalam konteks demikian, pada satu sisi, Kant ingin tetap mempertahankan objektivitas, universalitas, dan keniscayaan pengertian; dan di lain pihak, Kant menerima bahwa pengertian yang bertitik-tolak dari fenomena, dan tidak dapat melebihi batas-batasnya. Dengan demikian, Kant menginginkan bahwa pengetahuan dicapai melalui suatu perpaduan konsep dengan pengalaman. Artinya, Kant mencoba suatu sintesis apriori, yang bermuara pada analisis transendental mengenai pengetahuan manusia. Kant menekankan pengandaian-pengadaian dalam akal budi manusia yang mesti diterima supaya kesimpulan-kesimpulan ilmiah bisa dipertanggungjawabkan.

Sintesis di atas dikembangkan oleh Kant melalui pertanyaan apakah metafisika itu mungkin? Untuk menjawab persoalan itu, Kant mencoba menggunakan suatu kritik sistematis tentang pemikiran dan rasio manusia. Dia mencoba menjajagi tidak saja semua kepercayaan ilmiah, bahkan semua kepercayaan. Tujuannya adalah untuk memastikan apa yang digambarkan dalam tindakan keyakinan itu sendiri. Berbeda dengan apa yang dilakukan oleh para pemikir abad pertengahan, titik-tolak Kant lebih pada epistemologi daripada metafisika. Tujuan Kant adalah untuk mengkritik validitas ilmu pengetahuan, menguji operasionalitasnya, dan menentukan batas--batas ilmu pengetahuan itu sendiri. 
Upaya rekonstruksi inilah yang disebut oleh Kant sebagai "revolusi Copernican yang kedua". Artinya, sampai pada masa Kant terdapat anggapan umum bahwa pengertian manusialah yang harus menyesuaikan diri dengan objek-objek, tapi di tangan Kant objek-objeklah yang harus menyesuaikan diri dengan pengertian-pengertian manusia. Kant sendiri sebenarnya tidak menggunakan istilah "revolusi copernican", tetapi lebih merupakan analogi "revolusi cara berpikir' (revolution der denkart).

Oleh karena itulah Kant menyebut filsafatnya sebagai "filsa-fat transendental". Tujuan dari filsafat transendental adalah ingin menemukan dengan cara apa pikiran menggarap objek-objek dunia eksternal. Di samping itu, filsafat ini bertujuan untuk mengemukakan prinsipprinsip apriori sebagai hal yang fundamental dalam penyelidikan epistemologi.

\section{Dari Pembedaan Putusan ke Teori Pengetahuan Kritis}

Sebelum membahas teori pengetahuan kritisnya, Kant dalam Kritik der Reinen Vernunft, membedakan adanya tiga macam putusan. Untuk merumuskan tiga macam putusan tersebut, Kant membedakan dua macam putusan, yaitu putusan analitis apriori dan putusan sintesis aposteriori. ${ }^{8}$ Dalam putusan analitis yang bersifat apriori, setiap putusan yang terdiri dari pernyataan bahwa predikat $B$ sudah termuat dalam subjek A, meskipun masih kabur. Dalam menentukan putusan ini kita tidak usah mencari pengertian melalui pengalaman. Kita cukup menggunakan asas kontradiksi saja untuk mencapai putusan tersebut, karena subjek A sudah memuat seluruh predikat B Kant menyebut putusan semacam ini sebagai "putusan yang memperjelas" pengetahan kita. Namun, di lain pihak terlihat pula bahwa dengan putusan semacam ini kita tidak akan sanggup memperluas pengetahuan kita, sebab tidak ada sesuatu pengertian yang baru yang kita dapatkan, selain apa yang sudah terkandung dalam pengertian subiek A tersebut. Kant mengungkap hal tersebut di bawah ini:

${ }^{6}$ Henry D. Aiken, The Age of Ideology, The 19th Century Philo-sophers, (The New American Library, 1960), h. 13-15.

${ }^{7}$ Copleston, A History of Philosophy...., h. 180-185.

${ }^{8}$ Immanuel Kant, Critique of Pure Reason, Tranl. by J.M.D. Meiklejohn, (London: J.M.Dent \& Sons L.td, 1959), h. 26-30. 
"sebab tidak tepatlah mendasarkan keputusan analitis pada pengalaman, justru karena saya samasekali tidak usah keluar dari pengertian saya untuk menyusun keputusan itu, dan dengan demikian bukti dari pengalaman di sini tidak berguna".?

Sementara dalam putusan sintesis yang bersifata aposteriori, predikat $B$ berada di luar pengertian subjek $A$, maka adanya pengertian-pengertian dalam hubungan antara A dan B hanya nampak melalui pengalamanpengalaman kita mengenai benda A. Dengan demikian, berkat pengalamanpengalaman kita mengenai benda $A$ itulah pengetahuan kita menjadi makin bertambah luas. Sebagai contoh: semua benda itu berat. Untuk mendapatkan pengertian berat itu Kant mengatakan sebagai berikut:

"Sekarang saya meluaskan pengetahuan saya, dan selagi melihat kembali pengalaman dari mana saya memperoleh pengetahuan akan benda ini, saya mendapati juga 'berat'- nya setiap kali dihubungkan dengan sifatsifat di atas. Maka saya menambahkan secara sintesis 'berat' ini sebagai predikat terhadap pengetahuan itu. Pengalaman jugalah yang mendasari kemungkinan adanya sintesis antara predikat 'berat' dengan pengetahuan saya akan benda tadi; sebab pengetahuan itu, kendati yang satu tidak memuat yang lain, tetapi saling merupakan bagian dari satu keseluruhan yakni pengalaman yang sendirinya merupakan hubungan sintesis dari penginderaan-penginderaan meski hanya secara kebetulan saja". ${ }^{10}$

Lebih lanjut, Kant mengemukankan adanya suatu putusan lain dari dua putusan di atas, yaitu putusan sintesis apriori. Putusan ini merupakan putusan sintesis yang mempunyai sifat keniscayaan dan berlaku umum. Dalam hal ini pertolongan pengalaman tidak berguna lagi, justru karena dalam putusan tersebut terdapat unsur "umum" dan "niscaya". Kant mengungkapkan hal tersebut sebagai berikut:

"Hal ini bukan pengalaman, sebab asas yang tadi dikutip itu (asas bahwa segala sesuatu yang terjadi ada sebabnya) tidak hanya disertai keberlakuan umum melainkan disertai juga pernyataan akan keniscayaannya. Maka dengan demikian menjadi sama sekali apriori dan berasal dari pengertian saja ...". ${ }^{11}$

${ }^{9}$ Immanuel Kant, Critique of Pure Reason, Tranl. by J. M. D. Meiklejohn, (London: J. M. Dent \& Sons Ltd., 1959), h. 55.

${ }^{10}$ Kant, Critique of Pure Reason...., h. 101.

${ }^{11}$ Kant, Critique of Pure Reason...., h. 112. 
Putusan macam inilah yang menjadi sandaran ilmu pasti. Ata dasar putusan sintesis semacam inilah yang merupakan prinsip untuk memperluas pengetahuan, terletak seluruh tujuan terakhir semua pengetahuan spekulatif apriori kita ini, yang mencakup juga filsafat. Sebab meskipun putusan analitis itu sangat berguna, tetapi hanya sampai pada memperjelas pengetahuan saja, meskipun pengetahuan kita yang diperjelas itu akan berguna sekali untuk membentuk sintesis yang pasti dan luas lingkupnya, yang merupakan suatu penemuan yang sungguh-sungguh baru.

Sampai di sini, problem yang menghadang pikiran Kant adalah menyelidiki kemungkinan putusan-putusan sintesis apriori. Dalam bagian pendahuluan Critique, Kant sudah menyatakan: "How are synthetic apriorijudgments possible?"; dan menurut Kant, persoalan ini adalah "persoalan umum dalam rasio murni". ${ }^{12}$ Dari sinilah Kant mulai melakukan "Kritik atas Rasio Murni". Dalam hal ini Kant membedakan tiga tingkat pengenalan, yaitu pengenalan tingkat inderawi, pengenalan tingkat rasio, dan pengenalan tingkat akal-budi.

\section{Tingkatan-Tingkatan Pengetahuan Manusia}

Menurut Kant, terdapat tiga tingkatan dalam proses pengetahuan manusia. Tingkat pertama dan terendah adalah pencerapan inderawi (sinneswahrnemung). Tingkat berikutnya atau kedua adalah tingkat rasio (verstand). Terakhir atau ketiga adalah tingkat tertinggi dalam proses pengetahuan, yaitu adalah tingkat akal-budi atau intelek (vernunft).

\section{Tingkat Inderawi (sinneswabrebmung)}

Pengetahuan menurut Kant merupakan sintesis dari unsur-unsur apriori dengan unsur-unsur yang ada sebelum pengalaman, yakni unsurunsur aposteriori. Adapun unsur-unsur a priori, menurut Kant, sudah terdapat pada taraf pencerapan inderawi. Di sini sudah ada dua bentuk a priori, yaitu ruang dan waktu. Pengertian Kant mengenai ruang dan waktu ini berbeda dengan paham ruang dan waktu dalam pandangan Newton.

\footnotetext{
${ }^{12}$ Kant, Critique of Pure Reason...., h. 5.
} 
Kalau Newton menempatkan ruang dan waktu "di luar manusia", Kant mengatakan bahwa keduanya adalah a priori sensibilitas. Maksud Kant, keduanya sudah berakar di dalam struktur subjek. Ruang bukanlah ruang kosong, ke dalamnya suatu benda bisa ditempatkan; ruang bukanlah merupakan "ruang pada dirinya sendiri" (raum an sich). Sementara waktu bukanlah arus tetap, dimana penginderaan-penginderaan berlangsung. ${ }^{13}$ Bagi Kant, ruang dan waktu merupakan "bentuk formal" penginderaan. Dalam pencerapan inderawi kita mengatur kesan-kesan atau cerapancerapan pengamatan kita dalam ruang dan waktu. Bentuk pengamatan di dalam diri kita yang disebut ruang dan waktu itulah yang memungkinkan adanya penginderaan sesuatu. Bentuk mengatur atau membentuk kesankesan atau cerapan-cerapan inderawi yang lahiriyah, sedangkan bentuk waktu mengatur atau membentuk kesan-kesan atau cerapan-cerapan inderawi yang batiniah. Kedua pengertian ruang dan waktu ini mendahului penginderaan yang bersifat a posteriori, dan mewujudkan bentuk penginderaan apriori.

Implikasi dari pernyataan Kant di atas adalah memang ada realitas yang terlepas dari subjek. Menurut Kant, memang ada "benda pada dirinya sendiri" (das Ding an sich), tetapi realitas ini tidak bisa diamati atau diselidiki. Yang bisa diamati dan diselidiki hanyalah fenomenafenomena atau penampakan-penampakan (erscheinungen) realitas itu saja, yang senantiasa merupakan sintesis antara unsur-unsur yang datang dari luar sebagai materi dengan bentuk-bentuk apriori ruang dan waktu di dalam struktur pemikiran manusia.

\section{Tingkat Rasio (verstand)}

Bersama dengan pengamatan inderawi, bekerjalah rasio (verstand) secara spontan. Tugas rasio adalah menyusun dan menghubungkan datadata inderawi, sehingga menghasilkan putusan-putusan. Dalam hal ini, rasio bekerja dengan bantuan daya fantasinya (einbildungskraft). Namun demikian, dalam pandangan Kant, putusan ini belum merupakan pengetahuan rasio. Pengetahuan rasio, menurut Kant, diperoleh ketika terjadi sintesis antara

\footnotetext{
${ }^{13}$ Hartnack, Kant's Theory ...., h. 75-79.
} 
data-data inderawi dengan bentuk-bentuk a priori yang dinamai Kant sebagai "kategori", yakni ide-ide bawaan berupa "konsep-konsep pokok" yang mempunyai fungsi epistemologis dalam diri manusia. ${ }^{14}$

Menurut Kant, ada dua belas kategori dalam rasio. Kategori-kategori yang bersifat asasi adalah kategori-kategori yang menunjukkan kuantitas (kesatuan, kejamakan, keutuhan), kualitas (realitas, negasi, pembatasan), relasi (substansi dan aksiden, sebab dan akibat, interaksi), modalitas (mungkin/mustahil, ada/tiada, keperluan/kebutuhan). Lihat tabel ketegori rasio di bawah ini:

\begin{tabular}{|c|c|}
\hline Jenis Putusan & Kategori \\
\hline Kuantitas & Kuantitas \\
\hline 1. Putusan Universal & 1. Kesatuan/Unitas \\
\hline 2. Putusan Partikular & 2. Kemajemukan/Pluralitas \\
\hline 3. Putusan Singular & 3. Keseluruhan/Totalitas \\
\hline Kualitas & Kualitas \\
\hline 4. Putusan Afirmatif & 4. Realitas \\
\hline 5. Putusan Negatif & 5. Negasi \\
\hline 6. Putusan & 6. Limitasi \\
\hline Ketakberhinggaan & \\
\hline Relasi & Relasi \\
\hline 7. Putusan Kategoris & 7. Substansi \\
\hline Aksidensi & 8. Kausalitas \\
\hline 8. Putusan Hipotetis & 9. Komunitas \\
\hline 9. Putusan Disjuntif & \\
\hline Modalitas & Modalitas \\
\hline 10. Putusan Problematis & 10. Kemungkinan- \\
\hline 11. Putusan Penegasan & Kemustahilan \\
\hline 12. Putusan Apodiktis & 11. Eksistensi-Non-eksistensi \\
\hline & 12. Keniscayaan-Kontigensi \\
\hline
\end{tabular}

Tabel dikutip pada Franki Budi Hardiman, 2004: 141.

Dalam menerapkan kategori-kategori ini, rasio bekerja begitu rupa, sehingga ketegori-kategori ini hanya cocok dengan data-data yang dikenali saja. Kalau misalnya ada peristiwa bahwa setelah dipanaskan dengan api, maka air di dalam bejana menjadi mendidih. Oleh karena itu, rasio akan bekerja dengan menerapkan kategori kausalitas terhadap fenomenafenomena itu; dan kemudian membuat pernyataan "air di dalam bejana itu mendidih karena dipanaskan dengan api". Dengan demikian, terjadilah

\footnotetext{
${ }^{14}$ Hartnack, Kant's Theory of Knowledge ..., h. 85.
} 
sintesis antara unsur- unsur aposteriori, yaitu data-data inderawi yang berfungsi sebagai materi (api membakar bejana berisi air, dan air itu mendidih), dan unsur-unsur apriori yang berfungsi sebagai bentuk (kategori kausalitas). Dalam hal ini Kant menjelaskan sebagai berikut:

“... Reason has insight only into that which it produces after a plan its own, and that it must not allow itself to be kept, as it were, in nature's leadingstrings, but must itself show the way with principles of judgment based upon fixed laws, constraining nature to give answer to questions of reason's own determining. Accidental observations, made in obedience to no previously thought-out plan, can never be made to yield a necessary law, which alone reason is concerned to discover. Reason, holding in one hand its principles, according to which alone concordant appearances can be admitted as equivalent to laws, and in the order hand the experiment which it has devised in conformity with these principles, must approach nature in order to be taught by it. It must not, however, do so in the character of a pupil who listens to everything that the teacher chooses to say, but of an appointed judge who compels the witness to answer questions which he has himself formulated". ${ }^{15}$

Dalam hal ini kausalitas sangatlah penting. Hanya berdasar pada perbedaan antara yang bersifat mengikuti hukum dan yang bersifat sembarangan atau tanpa aturanlah kita membedakan yang objektif dan yang subjektif. Wahana objektif adalah wahana dari fenomena teratur. ${ }^{16}$ Dengan demikian, Kant juga menjelaskan sahnya ilmu pengetahuan alam dan menempatkan unsur subjektivisme sebagai interpretasi baru dari konflik-konflik filosofis abad itu.

\section{Tingkat Akal-Budi atau Intelek (vernunft)}

Yang dimaksud Kant dengan budi atau intelek (vernunft) adalah daya pencipta pengertian-pengertian murni atau pengertian-pengertian yang mutlak perlu, yang tidak diperoleh dari pengalaman melainkan mengatasi pengalaman itu sendiri. Salah satu darinya adalah ide mengenai Allah. Berbeda dengan rasio yang memuat di dalamnya kategori kategori, akalbudi atau intelek dengan idea-idea ini tidak ikut menyusun pengetahuan

${ }^{15}$ Kant, Critique of Pure Reason ..., h. 20.

${ }^{16}$ Kenneth T. Gallagher, Epistemologi; Filsafat Pengetahuan, disadur oleh P. Hardono Hadi, (Yogyakarta: Kanisius, 1994), h. 101. 
manusia. Idea-idea ini hanya bersifat "indikasi-indikasi kabur", petunjukpetunjuk buat pemikiran. Tugas akal-budi atau intelek adalah menarik kesimpulan dari pernyataan-pernyataan pada tingkat di bawahnya, yaitu rasio dan tingkat pencerapan inderawi. Dengan kata lain, intelek dengan idea-idea membuat argumentasi-argumentasi. Menurut Kant, ada tiga idea transendental. Pertama, idea psikologis (jiwa) yang merupakan gagasan yang mutlak yang mendasari segala gejala batiniah. Kedua, gagasan yang menyatukan segala gejala lahiriah, yakni idea kosmologis (dunia). Ketiga, gagasan yang mendasari segala gejala baik yang lahiriah maupun yang batiniah, yang terdapat dalam suatu pribadi yang mutlak, yakni Allah sebagai idea teologis. Ketiga idea ini tidak termasuk pengalaman, maka tidak mungkin ada pengetahuan rasio, baik filsafat, metafisika, maupun ilmu pengetahuan lainnya. ${ }^{17}$

Menurut Kant, pengalaman itu hanya terjadi di dalam dunia fenomenal, padahal ketiga idea tersebut berada di dunia nomenal, dunia gagasan, dan dunia batiniah. Idea mengenai jiwa, dunia, dan Allah bukanlah pengertian-pengertian tentang kenyataan inderawi, bukan "benda pada dirinya sendiri". Ketiga idea tersebut merupakan postulat atau aksioma-aksioma epistemologis yang berada di luar jangkauan pembuktian pengetahuan ilmiah.

Sampai di sini, Kant mempunyai prinsip dasar epistemologi bahwa seluruh pengetahuan manusia dimulai dari pengalaman. Menurut Kant, meskipun kita secara langsung berhubungan dengan objek-objek dunia, pikiran kita tidak dapat secara langsung berhubungan dengan entitas sebagaimana "mereka dalam dirinya" (as they are in themselves). Kita memiliki pengetahuan apriori hanya berkenaan dengan "penampakan" (appearances), bukan "benda dalam dirinya sendiri" (things as they are in themselves). ${ }^{18}$ Dari asumsi inilah, Kant mengembangkan teori tentang "dua dunia", yaitu dunia fenomenal dan dunia noemena. Dunia fenomena adalah dunia yang hadir di depan kita, yang ditentukan oleh bentuk-bentuk intuisi dan kategori-kategori pemahaman. Dunia fenomena

\footnotetext{
${ }^{17}$ Hartnack, Kant's Theory of Knowledge ..., h. 86-87.

${ }^{18}$ Kant, Critique of Pure Reason ..., h. 25.
} 
adalah dunia dimana objek-objeknya eksis tidak tergantung pada fikiran dan struktur pengetahuan manusia. ${ }^{19}$

Dalam konteks ini, adalah sebuah teka-teki yang tidak diselesaikan oleh Kant bagaimana tata hubungan antara dunia nomena dan dunia fenomena. Keketatan prinsip Kant pada struktur pemahaman tidak memungkinkan pemahaman yang melampaui batas-batas pengalaman atau mengatasi dunia fenomena. Masih berhadapan dengan teori "dua dunia" ini, Kant mendudukkan masalah Tuhan, dunia, dan jiwa sebagai "ide-ide transendental". Ide transendental berarti mengatasi seluruh pengalamman dan memberi dasar rasional yang ultimate bagi keberadaan fenomena sebagaimana mereka adanya. Tiga ide transendental ini tidak memiliki validitas sebagai objek pemahaman. Ide-ide transendental adalah ide-ide murni yang berfungsi "regulatif". Sekalipun demikian, jikalau rasio memikirkan ide-ide tersebut, hal itu bukanlah penyelewengan rasio, bukan suatu fantasi yang sewenang-wenang, sebab hal itu dilakukan berdasarkan keharusan berpikir. ${ }^{20}$

\section{Teori Pengetahuan dan Implikasi Terhadap Batas Ilmu}

Demikianlah Kant dalam Kritik ini mau menunjukkan kekeliruan dan keberatsebelahan yang ada pada filsafat rasionalisme ala Leibniz-Wolff dan skeptesisme Hume. Melawan Leibniz-Wolff, Kant mengatakan bahwa "rasio murni" saja tanpa pengalaman hanya akan menghasilkan khayalan belaka. Oleh karena itu, tidak ada pengetahuan a priori mengenai benda pada dirinya sendiri. Sedangkan menentang skeptisisme Hume, Kant, memperlihatkan bahwa pengetahuan sintesis a priori itu mungkin dan dapat diberikan contohnya. Kedua aliran besar dalam sejarah filsafat modern, rasionalisme dan empirisisme, kini bertemu dan sekaligus mencapai titik akhir dalam filsafat Kant, yang merupakan sintesis keduanya.

Namun demikian, penekanan Kant atas "subjek" dan "fenomena" membawa implikasi yang lebih jauh lagi pada corak paradigma ilmu pengetahuan modern. Jika pemikiran filosofis Descartes sering dikata-

\footnotetext{
${ }^{19}$ Kant, Critique of Pure Reason ...,h. 78.

${ }^{20}$ Kant, Critique of Pure Reason ..., h. 78-87
} 
kan sebagai pijakan awal terjadinya pergeseran pendulum paradigma manusia modern dari objek ke subjek, maka dalam konteks Kant, tidak hanya meradikalkan penekanan Descartes atas subjek juga memperlihatkan the conditions of possibility dari pikiran manusia. Penemuan batas-batas pikiran ini mengungkapkan suatu batas cakrawala pengetahuan sekaligus ilmu pengetahuan.

Oleh itulah, tidak mengherankan apabila sesudah Kant, sintesis ini Kant ini justru melahirkan aliran baru, yaitu positivisme. Aliran dengan tokoh utamanya Auguste Comte (1789-1857), John Stuart Mill (1806-1873), dan Herbert Spencer (1820-1903), ini lahir untuk melanjutkan pemikiran Kant tentang diktum yang sangat terkenal bahwa "apa yang dapat diselidiki hanyalah fenomena-fenomena belaka".

Dalam filsafat Kant, ilmu-ilmu alam menjadi asumsi normatif walaupun Kant masih mengakui keberadaan bentuk ilmu lain, seperti etika dan estetika. Namun perlu ditegaskan di sini, bahwa Kant secara implisit mencoba meletakkan ilmu-ilmu alam sebagai norma dan penelitian ilmiah sebagai kegiatan pengetahuan yang sahih. ${ }^{21}$ Konstruksi berpikir demikian semakin radikal dan memuncak pada positivisme Auguste Comte yang menekankan pengetahuan inderawi tidak hanya sebagai norma tetapi justru menjadi satu satunya norma bagi kegiatan pengetahuan. ${ }^{22}$ Oleh karena itu, tampilnya positivisme sebagai respon konstruktif terhadap pemikiran Kant tentang "apa yang dapat diselidiki hanyalah fenomena-fenomena belaka", selain membawa dampak atas terjadinya lagi pergeseran pendulum paradigma manusia modern menuju objek juga membawa dampak atas berakhirnya diskursus epistemologi itu sendiri dan dimulainya diskursus filsafat ilmu yang memusatkan diri pada penelitian metodologi. ${ }^{23}$

Dalam kajian filsafat ilmu, tendensi yang kemudian dianut secara berlebih-lebihan atas tampilnya positivisme itu adalah "objektivisme".

\footnotetext{
${ }^{21}$ Franki Budi Hardiman, "Ilmu-ilmu Sosial dalam Diskursus Modernisme dan PascaModernisme”, dalam Jurnal Ulumul Qur'an, (No.1, Vol. IV, Thn. 1994), h. 2.

${ }^{22}$ Richard Rarty, Philosophy and the Mirror of Nature, (New Jersey: Princeston Univ. Press, 1980), h. 132-133.

${ }^{23}$ Hardiman, "Ilmu-ilmu Sosial...., h. 3.
} 
Objektivisme tidak hanya menyalin fakta objektif, melainkan juga mengosongkan apa-apa saja dalam diri subjek sedemikian rupa sehingga menjadi fungsi-fungsi objektif dan mekanis. Dalam psikologi modern, yang mendasarkan diri pada observasi empiris, konsep-konsep seperti kecemasan, rasa bersalah, perilaku, dan pikiran, diformalisasikan dan dipermiskinkan sampai menjadi fungsi-fungsi dari suatu sistem objektif yang lebih luas. Demikian pula, dalam ilmu-ilmu yang menyangkut manusia, manusia diobservasi pada permukaan objektifnya sehingga apa-apa yang ditemukan dalam dimensi objektif manusia digenaralisasikan ke dalam dimensi subjektifnya pula. ${ }^{24}$

\section{Penutup}

Dari uraian bahasan yang telah dipaparkan di atas tampak dua kontradiksi dalam filsafat Kant. Satu sisi, Kant berhasil mendamaikan dua pertentangan epistemologi. Namun di sisi yang lain, Kant justru terjebak ke dalam pandangan yang sempit tentang ruang lingkup cakrawala ilmu pengetahuan modern. Seakan-akan Kant telah ikut mendorong dikeluarkannya ilmu-ilmu sosial-humaniora sebagai bagian dari rumpun ilmu pengetahuan ilmiah kecuali ilmu-ilmu ini mengikuti kaedah-kaedah positivisme [ ]

${ }^{24}$ Franki Budi Hardiman, Kritik Ideologi, (Yogyakarta: Kanisius, 1990), h. 22-25. 


\section{DAFTAR PUSTAKA}

Franz Magnis-Suseno, (1992). Filsafat sebagai Ilmu Kritis, Yogyakarta: Kanisius.

Franki Budi Hardiman, (1990). Kritik Ideologi, Yogyakarta: Kanisius.

—, (1994). "Ilmu-ilmu Sosial dalam Diskursus Modernisme dan Pascamodernisme", dalam Jurnal Ulumul Qur'an, No.1, Vol.IV.

- , (2004). Filsafat Modern: Dari Machiavelli sampai Nietæsche, Jakarta: Gramedia.

Frederick Copleston, (1960). A History of Philosophy, Vol. 6, (From Wolff to Kant), London: Burns and Oates Ltd.

Hendy D. Aiken, (1960). The Age of Ideology, The 19th Century Philosophers, The New American Library.

Immanuel Kant, (1959). Critique of Pure Reason, Transl. by J.M.D. .Weiklejohn, London: J.M.Dent \& Sons L.td.

John Cottingham, (ed), (1996). Western Philosophy; An Anthology, USA: Blackwell.

Justus Hartnack, (1967). Kant's Theory of Knowledge, (New York: Brace and World Inc.

Kennet T. Gallagher, (1994). Epistemologi; Filsafat Pengetabuan, disadur oleh P. Hardono Hadi, Yogyakarta: Kanisius.

M. Amin Abdullah, (1992). The Idea of Universality of Ethical Norms In Ghazali and Immanuel Kant, Ankara: Kutlu Doguma Armagan.

Richard Rorty, (1980). Philosophy and the Mirror of Nature, New Jersey: Princeston Univ. Press.

Toeti Heraty Noerhadi, (1994). "Dialog Filsafat dengan Ilmu-Ilmu Pengetahuan”, Pidato Pengukuhan Guru Besar, (Jakarta: Universitas Indonesia.

W. H. Walsh, "Immanuel Kant", dalam Paul Edwards (ed), (1967). The Encyclopadia of Philosophy, Vol.4, New York: Macmillan \& The Free Press. 